\title{
Impact of social interactions in the community on the transmission of tuberculosis in a high incidence area
}

Collette N Classen, Robin Warren, Madeleine Richardson, John H Hauman, Robert P Gie, James H P Ellis, Paul D van Helden, Nulda Beyers

\begin{abstract}
Background-Tuberculosis (TB) is transmitted by close contact with an infectious person. It is assumed that close contact occurs amongst household members and that contact outside the house is "casual" and does not play a major role in the transmission of TB.

Methods-This study was conducted in an impoverished area with a high incidence of TB and a low HIV seropositive prevalence. Thirty three households with $84 \mathrm{~TB}$ patients were identified between February 1993 and April 1996 and the transmission of TB was studied by combining Mycobacterium tuberculosis fingerprinting with in depth sociological interviews.

Results-Forty two strain genotypes were identified in the 84 patients. In 15 households all the patients had identical strains, in nine households all the patients had and in 12 of these households the patient(s) had contact with a community member who had the identical strain. In $58 \%$ of the cases the contact took place while drinking in social groups.

Conclusion-In high incidence areas contact outside the household may be important for the transmission of TB. This contact often takes place during recreation which, in the case of this study of impoverished people, consisted of drinking in social groups. Social interaction patterns should be studied and understood for effective implementation of control strategies.

(Thorax 1999;54:136-140)
\end{abstract}

Department of Anthropology/Sociology, University of the Western Cape, South Africa

C N Classen

J H P Ellis

Department of Paediatrics \& Child

Health, University of

Stellenbosch, South

Africa

R P Gie

$\mathrm{N}$ Beyers

MRC Centre for Molecular and Cellular Biology, Department of Medical

Biochemistry,

University of

Stellenbosch, South

Africa

R Warren

$M$ Richardson

J H Hauman

P D van Helden

Correspondence to: Dr C Classen, Department of Paediatrics and Child Health, University of Stellenbosch, PO Box 19063 , Tygerberg 7505, South Africa.

Received 29 July 1998 Returned to author 23 September 1998 Revised manuscript received 10 November 1998 Accepted for publication 11 November 1998

Keywords: tuberculosis; transmission; social interaction

Transmission of Mycobacterium tuberculosis occurs due to contact with an infectious individual $^{1}$ and several clinical and epidemiological studies of infection or disease after contact with tuberculosis (TB) have been published. ${ }^{23}$ Although households are regarded as places of close contact and high risk for transmission of TB, the exact definition of a "household" or "close contact" is not clear" and the relative importance of crowding or contact with a TB patient outside the household has not been established. ${ }^{256}$ Alcohol and drugs are regarded as risk factors for developing TB, ${ }^{6-8}$ but it is uncertain whether susceptibility to TB is increased by the alcohol and drugs per se, or by the fact that alcohol and drug users may be in close contact with untreated TB patients.

DNA fingerprinting of $M$ tuberculosis strains by the insertion element IS6110 has recently indicated that, in patients with identical strains who are considered to reflect a chain of recent transmission, social contact could be proved only in a minority of cases. $^{9}{ }^{10}$ Additional probes $^{11}{ }^{12}$ classify $M$ tuberculosis more accurately into clusters, thereby increasing the likelihood of finding contact between patients. ${ }^{11}$ Limited variation has been recorded in $M$ tuberculosis strains from households ${ }^{13}$ and close contacts, ${ }^{14}$ suggesting transmission of $M$ tuberculosis. However, in these studies the possibility that the transmission might have taken place in the community was not addressed.

The aim of this study was to investigate the transmission of TB in households by using IS6110 and MTB484(1) DNA fingerprinting of $M$ tuberculosis organisms from patients in the same household, combined with an in depth anthropological assessment of social interaction patterns in a high incidence area.

\section{Methods}

The study was performed between February 1993 and April 1996 in the Western Cape Province of South Africa where the tuberculosis notification rate for 1995 was $682 / 100000^{15}$ and the prevalence of HIV seropositivity is just more than $1 \% .{ }^{16}$ The tuberculosis notification rate in the suburbs studied (population 34 294, surface area $2.42 \mathrm{~km}^{2}$ ) was $>1000 / 100000 .{ }^{17}$ Treatment for TB is provided by two local authority health clinics and patients receive a six month antituberculosis treatment regimen daily under direct supervision (DOTs).

During the study period all sputum samples of TB patients were cultured by radiometric assay (BACTEC ${ }^{\circledR}$ ) and subcultured onto Löwenstein-Jensen slants. DNA was isolated and genotyped by IS6110 and MTB484(1). ${ }^{11} 18$ The IS6110 DNA fingerprints were analysed using GelCompar software and compared using the UPGMA and Dice coefficients. ${ }^{19}$ The MTB484(1) DNA fingerprints were analysed visually.

$M$ tuberculosis strains were classified into clusters if two or more people had an identical strain with both probes. If a number of people in different households had the identical strain 
it was called a "community cluster". If all the people with an identical strain lived in the same household the strain was called a "unique household cluster". If a strain did not match any other strain from the community it was called a "unique strain".

Information regarding contact between patients was obtained by a medical anthropologist through informal interviews conducted in patients' homes or in a secluded part of the clinic. Occasionally patients were met in neighbourhood bars in order to observe the alcohol consumption and the social contact in these bars. Confidentiality was maintained at all times.

We defined a household as a house and associated informal dwelling(s) at the same address on the same plot of land. Plot sizes ranged in size from $250 \mathrm{~m}^{2}$ to $800 \mathrm{~m}^{2}$, there was always a single entrance to the plot and access to the associated informal dwellings was obtained by walking through the main house.

\section{Results}

IS6110 AND MTB484(1) FINGERPRINTING AND SOCIAL INTERVIEWS

During the study period (February 1993 to April 1996) 622 patients residing in the area were shown to be infected with $M$ tuberculosis organisms, having 283 different banding patterns on IS6110 fingerprinting, and the degree of clustering was calculated at $40-50 \%$. During this period 44 of the 5345 households in the community were identified in which two or more household members had cultures positive for $M$ tuberculosis. Eleven households were excluded from the study as all the household members could not be interviewed (in one household both patients had died while at least one patient of each of the remaining 10 households had moved). The final sample consisted of 33 households with 84 patients who were all interviewed and whose cultures revealed $42 \mathrm{M}$ tuberculosis strains. There were 26 households $(79 \%)$ in which at least one patient had a strain which formed part of a community cluster. In five of the 33 households there was a strain of $M$ tuberculosis shared by the patients in that specific household but which did not occur in any other member of the community (unique household clusters). Of the 84 patients 14 (17\%) had a unique $M$ tuberculosis strain not shared by any other patient in the community.

The households were grouped into three different categories.

(1) Households where patients in each house had identical strains

In all 15 households where the patients within the same household had identical $M$ tuberculosis strains the patients in the same household shared the same dwelling (table 1) and in 14 households the patients were close relatives. In

Table 1 Data of patients and Mycobacterium tuberculosis strains in households where all patients per household had the identical strain of M tuberculosis

\begin{tabular}{|c|c|c|c|c|c|c|c|}
\hline Household & $\begin{array}{l}\text { No. of bands } \\
\text { with IS6110 }\end{array}$ & $\begin{array}{l}\text { No. of patients } \\
\text { with identical } \\
\text { strains }\end{array}$ & Relationship & $U C / C C$ & $\begin{array}{l}\text { No. of other people } \\
\text { in community } \\
\text { cluster }\end{array}$ & $\begin{array}{l}\text { No.of household } \\
\text { patients drinking in } \\
\text { social group }\end{array}$ & $\begin{array}{l}\text { No. of other people in } \\
\text { community cluster in contact } \\
\text { with patient(s) }\end{array}$ \\
\hline 1 & 11 & $2^{\star}$ & Uncle and niece & $\mathrm{CC}$ & 2 & 1 & 0 \\
\hline 2 & 19 & $4^{\star}$ & Brothers and sister, daughter & $\mathrm{CC}$ & 7 & 3 & 1 \\
\hline 3 & 4 & $2^{\star}$ & Common-law spouses & $\mathrm{CC}$ & 15 & 2 & $3(\mathrm{~s})$ \\
\hline 4 & 3 & $2^{\star}$ & Ex-spouses & UC & - & 1 & \\
\hline 5 & 3 & $2^{\star}$ & Brothers & $\mathrm{CC}$ & 3 & 2 & 0 \\
\hline 6 & 1 & $2^{\star}$ & Friends & $\mathrm{CC}$ & 6 & 2 & $1(\mathrm{~s})$ \\
\hline 7 & 4 & $2^{\star}$ & Mother and son & $\mathrm{CC}$ & 4 & 1 & 0 \\
\hline 8 & 9 & $2^{\star}$ & Father and son & CC & 2 & 2 & 0 \\
\hline 9 & 14 & $2^{\star}$ & Father and son & UC & - & 1 & \\
\hline 10 & 9 & $3^{\star}$ & Mother, daughter and cousin & UC & - & 1 & \\
\hline 11 & 14 & $2^{\star}$ & Spouses & $\mathrm{CC}$ & 3 & 1 & 0 \\
\hline 12 & 17 & $2^{\star}$ & Mother and son & $\mathrm{CC}$ & 1 & 2 & 0 \\
\hline 13 & 5 & $2^{\star}$ & Common-law spouses & $\mathrm{CC}$ & 8 & 2 & 1 \\
\hline 14 & 14 & $2^{\star}$ & Brother and cousin & $\mathrm{CC}$ & 2 & 2 & $1(\mathrm{~s})$ \\
\hline 15 & 14 & $6^{\star}$ & $\begin{array}{l}\text { Brothers, sister and sister's } \\
\text { boyfriend }\end{array}$ & $\mathrm{CC}$ & 10 & 6 & 0 \\
\hline
\end{tabular}

$\mathrm{UC}=$ unique household cluster; $\mathrm{CC}=$ community cluster; ${ }^{\star}$ same dwelling; $(\mathrm{s})$ = social contact took place while drinking.

Table 2 Data of patients and Mycobacterium tuberculosis strains in households where each patient in a household had a different strain of $M$ tuberculosis

\begin{tabular}{|c|c|c|c|c|c|c|c|}
\hline Household & $\begin{array}{l}\text { No. of bands } \\
\text { with IS6110 }\end{array}$ & $\begin{array}{l}\text { No. of patients with } \\
\text { identical strains }\end{array}$ & Relationship & $U / U C / C C$ & $\begin{array}{l}\text { No. of other people } \\
\text { in cluster }\end{array}$ & $\begin{array}{l}\text { No. of household patients } \\
\text { drinking in social group }\end{array}$ & $\begin{array}{l}\text { No. of other people in community } \\
\text { cluster in contact with patient (s) }\end{array}$ \\
\hline \multirow[t]{2}{*}{1} & 12 & $2^{\star}$ & $\begin{array}{l}\text { Uncle and } \\
\text { niece }\end{array}$ & $\mathrm{U}$ & - & 1 & - \\
\hline & 4 & & & CC & 6 & & 1 \\
\hline \multirow[t]{2}{*}{2} & 10 & $2^{\star}$ & Tenant & CC & 1 & 2 & 0 \\
\hline & 15 & & & $\mathrm{U}$ & - & & - \\
\hline \multirow[t]{2}{*}{3} & 12 & $2+$ & Tenant & $\mathrm{U}$ & - & 1 & - \\
\hline & 14 & & & $\mathrm{U}$ & - & & - \\
\hline \multirow[t]{2}{*}{4} & 11 & $2+$ & Tenant & $\mathrm{CC}$ & 4 & 2 & $3(\mathrm{~s})$ \\
\hline & 21 & & & CC & 1 & & 0 \\
\hline \multirow[t]{2}{*}{5} & 10 & $2^{\star}$ & Tenant & $\mathrm{U}$ & - & 2 & - \\
\hline & 12 & & & $\mathrm{CC}$ & 1 & & 1 \\
\hline \multirow[t]{2}{*}{6} & 9 & $2 \dagger$ & Cousins & CC & 10 & 2 & 0 \\
\hline & 12 & & & $\mathrm{CC}$ & 2 & & 0 \\
\hline \multirow[t]{2}{*}{7} & 9 & $2^{\star}$ & Spouses & $\mathrm{U}$ & - & 2 & - \\
\hline & 14 & & & $\mathrm{U}$ & - & & - \\
\hline \multirow[t]{2}{*}{8} & 14 & $2^{\star}$ & Tenant & $\mathrm{CC}$ & 3 & 2 & 0 \\
\hline & 15 & & & CC & 5 & & $2(\mathrm{~s})$ \\
\hline \multirow[t]{2}{*}{9} & 15 & $2 \dagger$ & Tenant & $\mathrm{U}$ & - & 2 & - \\
\hline & 4 & & & $\mathrm{U}$ & - & & - \\
\hline
\end{tabular}




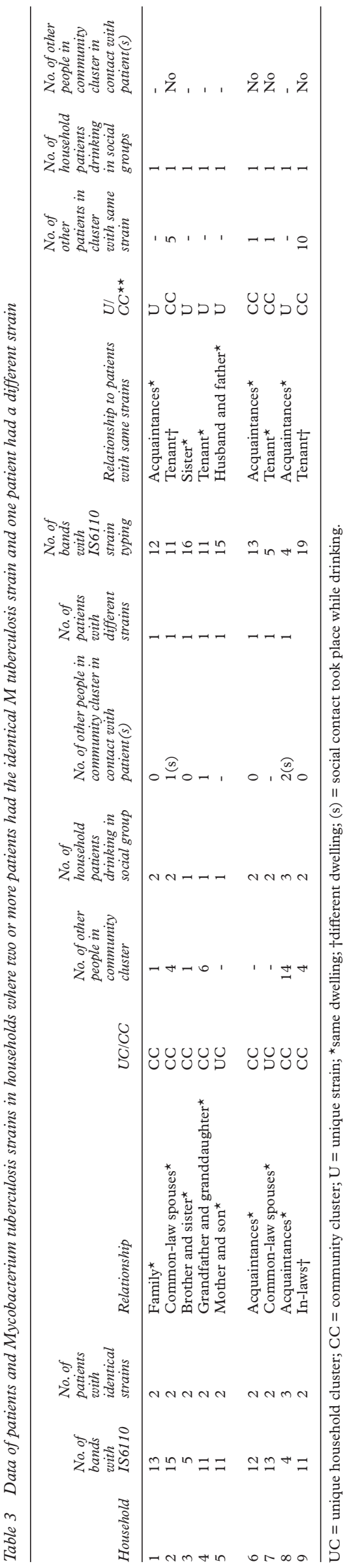

three of the households the patients in the household had identical $M$ tuberculosis organisms which formed a unique household cluster and the organism did not form part of a bigger cluster shared by other patients in the community. In 12 households the $M$ tuberculosis strain formed part of a bigger community cluster (on average six other people in the cluster). At least one patient per household regularly drank in social groups with community members who had tuberculosis. In patients from five households, close contact with a community member with an identical $M$ tuberculosis strain could be confirmed and in patients from three of the five households $(60 \%)$ this contact occurred while drinking in social groups.

(2) Households where each patient in the household had a different strain

Of the 18 patients living in the nine households where patients in each household had different $M$ tuberculosis strains, nine had unique strains and nine had strains which formed part of a community cluster (on average four other patients in the cluster; table 2). Regular drinking in social groups occurred in 16 of the 18 patients. In four patients whose strain formed part of a community cluster, contact with other community members with the identical $M$ tuberculosis strain could be proved, and in two of the four cases this contact took place while drinking in social groups. In only two of the nine households were the patients close relatives or spouses, and in six of the nine households the patients lived in the same dwelling.

(3) Households where at least two patients had identical strains and at least one patient had a different strain

There were nine households with a total of 28 patients where two or more patients with TB in the same household had identical $M$ tuberculosis strains and an additional patient had a strain different from the others (table 3). There were 19 patients in eight of the households who had an $M$ tuberculosis strain which formed part of a community cluster and 17 of these regularly drank in social groups. In three cases close contact with other patients in the community who had the identical $M$ tuberculosis strain was identified and in two of the three cases the contact occurred while drinking in social groups. In all the households the patients who had identical $M$ tuberculosis strains lived in the same dwelling and in six of the nine dwellings these patients were relatives. In three of the households the patient with the different $M$ tuberculosis strain lived in a different dwelling on the same plot of land.

DRINKING IN SOCIAL GROUPS

Social contact outside the household was established in members of 12 of the 26 households where the $M$ tuberculosis strains in the household formed part of a community cluster. In seven of these 12 households (58\%) this contact took place during drinking in social groups. Of the 84 patients in this household study, $62(74 \%)$ regularly drank in social 
groups. This type of drinking took place either in a local neighbourhood informal bar (shebeen) or in small gatherings at peoples' homes. In the shebeens 30-40 people drank together in a space of about $35 \mathrm{~m}^{2}$, while in the homes usually 3-6 people gathered in a 9-10 $\mathrm{m}^{2}$ area while drinking. Each patient drank 4-5 times per week and would often spend up to 30 hours a week drinking in social groups.

\section{Discussion}

There have been numerous reports of TB and of skin test conversion amongst family members, ${ }^{25}$ suggesting transmission in the house. Recently two reports of family members or closely associated individuals living in the same house $\mathrm{e}^{1314}$ indicated limited variation in the RFLP patterns, suggesting transmission in the house. No indication is given on their possible contact with other TB patients outside the house.

In communities where people live in overcrowded conditions one would expect that, if two or more people in one household have TB, their $M$ tuberculosis strains would be identical. Our findings from an area with a high incidence of TB demonstrate that, when two or more people in the same household have TB, they do not always have the same strain of $M$ tuberculosis and therefore household transmission cannot always be implied. Transmission as defined by identical $M$ tuberculosis strains occurred more commonly in patients who were relatives living in the same dwelling than in non-related individuals or if relatives lived in different dwellings. We have found that, in 18 of the $33(55 \%)$ households, at least one patient had a strain which was not shared by another household member, suggesting that tuberculosis is being transmitted either outside the households or occurs due to reactivation of latent infection. In seven of these households the different strain could be explained by the fact that one patient of each household lived in a separate dwelling (backyard shack). In the community studied, where there is a high incidence of TB (>1000/100 000/year) and where people live in conditions of poverty, the difficulty of tracing the transmission of TB is illustrated by the complexity of the household structures where living at the same address does not always imply living in the same dwelling. Even when people live in the same dwelling they often do not even know each other as their living arrangements are merely business transactions and do not necessarily imply close contact with each other.

Our study suggests that, even when household members have identical $M$ tuberculosis strains, transmission within the household cannot be assumed since the $M$ tuberculosis strain in 59 of the 84 patients $(70 \%)$ in these households formed part of a community cluster. In 12 of the households contact with nonhousehold members with the identical $M$ tuberculosis strain had taken place and in seven of these $12(58 \%)$ households contact took place while drinking in social groups. During these regular drinking episodes very close con- tact (kissing, hugging, dancing) occurred in confined spaces (1-2 $\mathrm{m}^{2}$ per person).

Contact outside the house or the family including casual, short periods of contact amongst family members and co-workers or casual contact in a physician's office, ${ }^{21}$ in shelters for the urban homeless, ${ }^{22-24}$ housing facilities for HIV positive patients, ${ }^{25}$ a church choir, ${ }^{26}$ a church, ${ }^{27}$ and in a crack house ${ }^{28}$ has been reported as important in the transmission of TB. A neighbourhood bar has been implicated in the transmission of TB amongst its regular patrons, but without RFLP evidence. ${ }^{29}$ Transmission of TB in bars has been proved by RFLP data, but only in HIV infected individuals. ${ }^{30}$ These studies all looked at the transmission of TB within relatively confined areas and did not report the effect of transmission of TB in the wider community outside these confined areas.

We therefore suggest that, while in low incidence areas transmission of TB often takes place in confined areas like the household, in high incidence areas contact outside the house may play a major role in the transmission of TB. In our study, in an economically depressed area with no recreation except for social drinking, we found that $74 \%$ of all the patients drank regularly in social groups. Our findings further indicate that contact outside the house is not necessarily "casual" and that, while drinking in social groups, very close and intimate contact occurred which could easily have contributed to the transmission of TB. Similar conditions are probably prevailing in many other developing countries with high incidences of TB, thus making extrapolation from studies on the transmission of TB in low incidence developed countries impossible and dangerous. We suggest that the social interaction patterns in a community should be studied before the transmission of TB in the area can be properly understood and effective TB control strategies can be put into place.

We are indebted to the people of Uitsig and Ravensmead who effortlessly allowed us a glimpse into very personal spheres of their lives, Mrs S M Carlini and Mrs M Bosman for help with the $M$ tuberculosis cultures, Dr I Toms and Dr T Fish for permission to conduct the study in the local authority health clinics, Glaxo Wellcome Action TB Research Program for financial support, and the Commission of the European Communities, Directorate General XII, Biomedical and Health Communities, Directorate General XII, Biomedical and Health ance with the Gelcompar software

1 Coovadia HM, Benatar SR. A century of tuberculosis. Cape Town: Oxford University Press, 1991.

2 Chapman JS, Dyerly MD. Social and other factors in intrafamilial transmission of tuberculosis. Am Rev Respir Dis 1964;90:48-60.

3 Narain R, Nair SS, Rao GR, et al. Distribution of tuberculous infection and disease among households in a rural community. Bull World Health Org 1966;34:639-54.

4 Lomnitz L. Networks and marginality. Life in a Mexican shanty town. New York: Academic Press, 1977.

5 Hussain SF, Watura R, Cashman B, et al. Tuberculosis contact tracing: are the British Thoracic Society guidelines still appropriate? Thorax 1992;47:984-5.

6 Coetzee N, Yach D, Joubert G. Crowding and alcohol abuse as risk factors for tuberculosis in the Mamre population. $S$ Afr Med F 1988;74:352-4.

7 Enarson DA, Wang J, Dirks JM. The incidence of active tuberculosis in a large urban area. Am 7 Epidemiol 1989;129:1268-76.

8 Bloch AB, Onorato IM, Ihle WW, et al. The need for epidemic intelligence. Public Health Rep 1996;111:26-31.

9 Alland D, Kalkut G E, Moss AR, et al. Transmission of tuberculosis in New York City: an analysis by DNA fingerprinting and conventional epidemiologic methods. N Engl f Med 1994;330:1710-16. 
10 Small PM, Hopewell PC, Sing SP, et al. The epidemiology of tuberculosis in San Francisco: population-based study using conventional

11 Warren RM, Richardson M, Sampson S, et al. Genotyping of Mycobacterium tuberculosis with additional markers enhances accuracy in epidemiological studies. $\mathcal{F}$ Clin Microbiol 1996;34:2219-24.

12 Burman WJ, Reeves RR, Hawkes AP, et al. DNA fingerprinting with two probes decreases clustering of Mycobacterium tuberculosis. F Clin Microbiol 1996;34:221924 .

13 Mazurek GH, Cave MD, Eisenach KD, et al. Chromosomal DNA fingerprint patterns produced with IS6110 as strainspecific markers for epidemiologic study of tuberculosis. $f$ Clin Microbiol 1991;29:2030-3.

14 Huh YJ, Ahn DI, Kim SJ. Limited variation of DNA fingerprints (IS6110 and IS 1081) in Korean strains of Mycobacte-

15 Department of Health, Republic of South Africa. Notifiable medical conditions. Epidemiological Comments 1996;23:22.

16 Department of Health, Republic of South Africa. Sixth national HIV survey of women attending antenatal clinics of the public health services in the Republic of South Africa, October/November 1995. Epidemiological Comments 1996;33(1):14

17 Beyers N, Gie RP, Zietsman HL, et al. The use of geographical information system (GIS) to evaluate the distribution of tuberculosis in a high incidence community. $S$ Afr Med F 1996;86:40-4.

18 Warren R, Hauman J, Beyers $\mathrm{N}$, et al. Unexpectedly high strain diversity of Mycobacterium tuberculosis in a high incidence community. $S$ Afr Med F 1996;86:45-9.

19 Hermans PWM, Messadi F, Guebrexabher H, et al. Analysis of the population structure of Mycobacterium tuberculosis in Ethion, Tunis a 1504-13.
20 Festenstein F. Spread of tuberculosis within a family. Lancet $1981 ; \mathrm{i}: 603-5$

21 Valway SE, Sanchez MPC, Shinnick TF, et al. An outbreak nvolving extensive transmission of a virulent strain of Mycobacterium tuberculosis. N Engl $\mathcal{F}$ Med 1998;338:633-9.

22 Barnes PF, El-Haji H, Preston-Martin S, et al. Transmission of tuberculosis among the urban homeless. $7 A M A$ 1996;24:305-7.

23 Barnes PF, Yang Z, Preston-Martin S, et al. Patterns of tuberculosis transmission in central Los Angeles. $7 A M A$ 1997;278:1159-63.

24 Gutierrez MC, Vincent V, Aubert D, et al. Molecular fingerprinting of Mycobacterium tuberculosis and risk factors for tuberculosis transmission in Paris, France, and surrounding area. F Clin Microbiol 1998;36:486-92.

25 Daley CL, Small PM, Schecter GF, et al. An outbreak of tuberculosis with accelerated progression among persons infected with the Human Immunodeficiency Virus. $N$ Engl f Med 1992;326:231-5.

26 Mangura BT, Napolitano EC, Passannante MR, et al. Mycobacterium tuberculosis miniepidemic in a church gospel choir. Chest 1998;113:234-7.

27 Dutt AK, Mehta JB, Whitaker BJ, et al. Outbreak of tuberculosis in a church. Chest 1995;107:447-52.

28 Leonhardt KK, Gentile F, Gilbert BP, et al. A cluster of tuberculosis among crack house contacts in San Mateo County, California. Am f Public Health 1994;84:1834-6.

29 Kline SE, Hedemark LL, Davies SF. Outbreak of tuberculosis among regular patrons of a neighborhood bar. N Engl f Med 1995;333:222-7.

30 Tabet SR, Goldbaum GM, Hooton TM, et al. Restriction fragment length polymorphism analysis detecting a community-based tuberculosis outbreak among persons infected with human immunodeficiency virus. F Infect Dis 1994;169:189-92. 